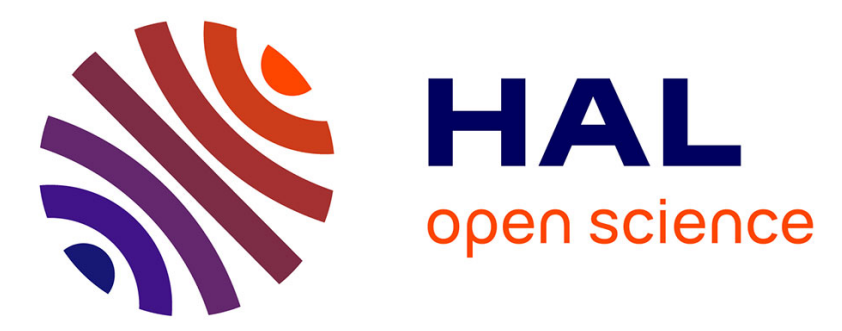

\title{
Chemical, physical, and optical characterization of aerosols during PAUR II experiment
}

G. Kouvarakis, Y. Doukelis, N. Mihalopoulos, S. Rapsomanikis, J. Sciare, M. Blumthaler

\section{- To cite this version:}

G. Kouvarakis, Y. Doukelis, N. Mihalopoulos, S. Rapsomanikis, J. Sciare, et al.. Chemical, physical, and optical characterization of aerosols during PAUR II experiment. Journal of Geophysical Research, 2002, 107 (D18), 10.1029/2000JD000291 . hal-03127114

\section{HAL Id: hal-03127114 \\ https://hal.science/hal-03127114}

Submitted on 2 Feb 2021

HAL is a multi-disciplinary open access archive for the deposit and dissemination of scientific research documents, whether they are published or not. The documents may come from teaching and research institutions in France or abroad, or from public or private research centers.
L'archive ouverte pluridisciplinaire HAL, est destinée au dépôt et à la diffusion de documents scientifiques de niveau recherche, publiés ou non, émanant des établissements d'enseignement et de recherche français ou étrangers, des laboratoires publics ou privés. 


\title{
Chemical, physical, and optical characterization of aerosols during PAUR II experiment
}

\author{
G. Kouvarakis, ${ }^{1}$ Y. Doukelis, ${ }^{2}$ N. Mihalopoulos, ${ }^{1}$ S. Rapsomanikis,${ }^{2}$ J. Sciare,${ }^{3}$ and \\ M. Blumthaler ${ }^{4}$
}

Received 27 December 2000; revised 20 March 2001; accepted 16 April 2001; published 28 September 2002.

[1] During a 1-month campaign conducted in May 1999 in the frame of Photochemical Activity and Solar Ultraviolet Radiation (PAUR II) project, determination of the ionic composition and physical and optical properties of the aerosol have been performed at a coastal site in Crete. Non-sea-salt sulfate (nss- $\left.\mathrm{SO}_{4}{ }^{2-}\right)$, nitrate $\left(\mathrm{NO}_{3}{ }^{-}\right)$non-sea-salt calcium $\left(\right.$ nss- $\left.\mathrm{Ca}^{2+}\right)$, and ammonium $\left(\mathrm{NH}_{4}^{+}\right)$have been identified as the main non-sea-salt ionic components of the aerosol. Air mass origin was found to be an important factor controlling the variation of the above ions as well as their particle size distribution. During the experiment, aerosol scattering coefficient ranges from 2 to $51\left(\mathrm{M} \mathrm{m}^{-1}\right)$ with no significant difference between dusty and nondusty periods. Significant correlations have been observed between $\left(\mathrm{NH}_{4}\right)_{2} \mathrm{SO}_{4}$ mass measured during the campaign, aerosol scattering coefficient, and aerosol single-scattering albedo indicating the key role of $\left(\mathrm{NH}_{4}\right)_{2} \mathrm{SO}_{4}$ in determining the radiative forcing of the eastern Mediterranean area. Finally, non-sea-salt calcium was found to better reproduce the variation of optical depth, more than any other ionic species. INDEX TERMS: 0305 Atmospheric Composition and Structure: Aerosols and particles (0345, 4801); 0345 Atmospheric Composition and Structure: Pollution-urban and regional (0305); 0365 Atmospheric Composition and Structure: Troposphere-composition and chemistry; 0368 Atmospheric Composition and Structure: Troposphere-constituent transport and chemistry;

KEYWORDS: aerosol composition; regional pollution; dust episode; mass scattering coefficient; optical depth; radiative forcing

Citabion: Kouvarakis, G., Y. Doukelis, N. Mihalopoulos, S. Rapsomanikis, J. Sciare, and M. Blumthaler, Chemical, physical, and optical characterization of aerosols during PAUR II experiment, J Geophys Res., 107(D18), 8141, doi:10.1029/2000JD000291, 2002.

\section{Introduction}

[2] The potential role of tropospheric aerosol in regulating climate through backscattering and absorption of solar radiation and formation of cloud condensation nuclei (CCN) has been established during the last years [Intergovernmental Panel on Climate Change (IPCC), 1996]. Aerosol scatters and/or absorbs short wavelength (UV-visible) light, hence influencing directly the radiative balance of the Earth [Charlson et al., 1991] possibly, with a sign (radiative cooling) opposite to that of greenhouse gases [IPCC, 1996]. Model calculations by Charlson et al. [1991] assuming that the aerosol is mainly composed by $\left(\mathrm{NH}_{4}\right)_{2} \mathrm{SO}_{4}$ show that the eastern Mediterranean is one of the areas, worldwide, which could be very strongly influenced by the negative radiative forcing induced by the aerosols.

[3] This is due to the fact that the eastern Mediterranean can be affected by two and sometimes three strong, but very different in composition, aerosol sources: Sahara desert, indus-

\footnotetext{
${ }^{1}$ Environmental Chemical Processes Laboratory, Department of Chemistry, University of Crete, Heraklion, Greece.

${ }^{2}$ Laboratory of Air Pollution, Department of Environmental Engineering, Demokritos University of Thrace, Xanthi, Greece.

${ }^{3}$ LSCE, Orme des Merisiers, Gif-sur-Yvette, France.

${ }^{4}$ Institute of Medical Physics, University of Innsbruck, Innsbruck, Austria.

Copyright 2002 by the American Geophysical Union. 0148-0227/02/2000JD000291\$09.00
}

trialized area of N/NW Europe, and sea spray [Dayan et al., 1991; Mihalopoulos et al., 1997; Moulin et al., 1997a, 1997b]. However, for the eastern Mediterranean area only few studies have been performed in the background atmosphere focusing either on the ionic composition of aerosols [Mihalopoulos et al., 1997], on fine organic aerosols [Gogou et al., 1994] and or on transport of Saharan dust [Ganor and Mamane, 1982]. Up to now, very few experiments have tried to relate the chemical composition of aerosol with its optical properties [Kavouras et al., 1996; Ichoku et al., 1999]. Ichoku et al. [1999] reported interrelationships between aerosol characteristics and light scattering during late winter in an eastern Mediterranean arid environment. These authors showed that during strong dust events, almost all of the solar radiation reaching the area is scattered or absorbed.

[4] The data presented here have been collected at a coastal rural site on the island of Crete in the eastern Mediterranean area exposed to the N/NW winds, during the PAUR II experiment in May 1999. The month of May was choosen because during that period air masses originating from all potential aerosol sources (desert, sea, and industrialized areas of N/NW Europe) are reaching the island [Mihalopoulos et al., 1997]. Since the highest atmospheric mass loadings are due to mineral dust, sea-salt and nss-sulfate, the choice of the site, was ideal for the study of the effects of the aerosol scattering on the light attenuation at the Earth's surface. More details about PAUR II experiment are given by Zerefos [2002]. To our knowledge, the work presented here is the first attempt to 


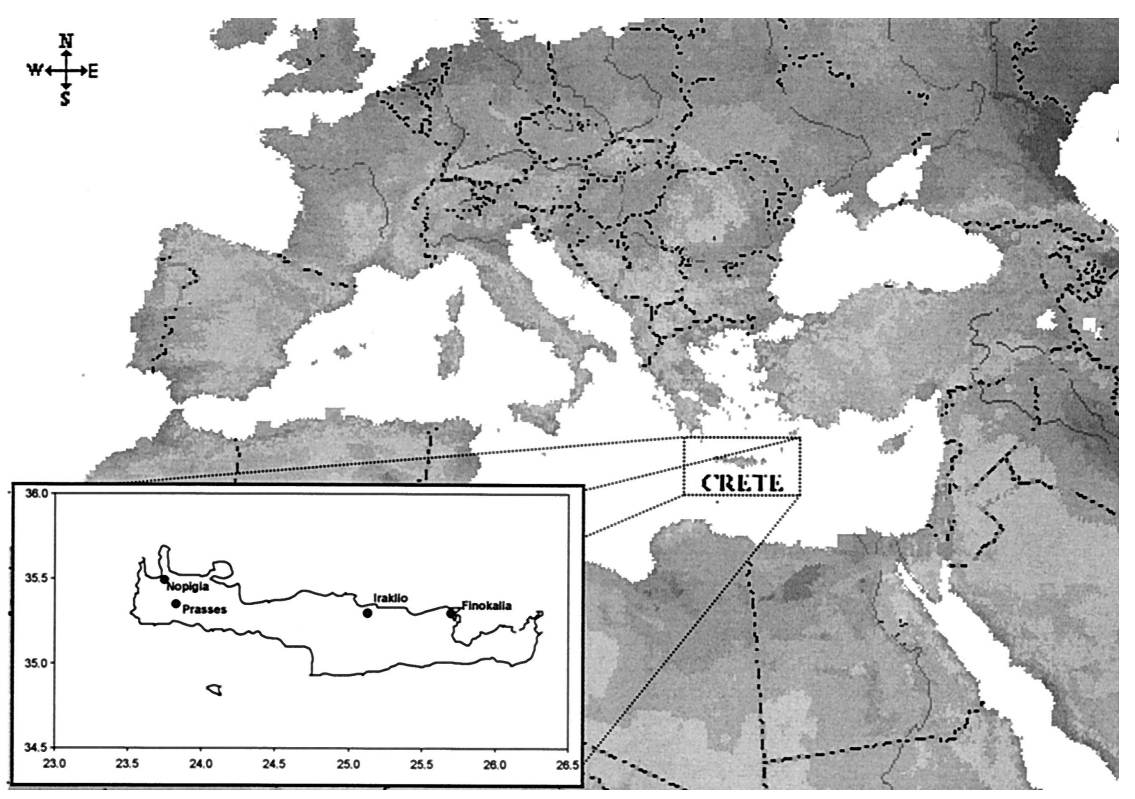

Figure 1. Map of Crete indicated the location of the sampling sites referenced in the text.

relate the ionic composition of aerosols in the background atmosphere of the southern part of the eastern Mediterranean region, with their physical and optical characteristics.

\section{Experiment}

\subsection{Sites}

[5] During the PAUR II experiment, aerosols have been collected at two places in the western Crete (Nopigia and Prasses, Figure 1). Prasses is a small village located at $1030 \mathrm{~m}$ of altitude and Nopigia is a coastal site. The results regarding the ionic composition from this experiment have been compared with those collected on a routine basis at Finokalia $\left(25^{\circ} 60^{\prime} \mathrm{E}, 35^{\circ} 24^{\prime} \mathrm{N}\right)$ in the northern coast of Crete (Figure 1). Details about Finokalia can be found elsewhere [Mihalopoulos et al., 1997; Kouvarakis et al., 2000].

\subsection{Sampling and Analysis of Filters}

[6] At Nopigia and Prasses, size-segregated aerosols were collected on Whatman-41 filter paper using a commercially available Sierra Anderesen six-stage impactor (SierraAndersen, Model 230 impactor; hereafter mentioned as "HiVol"). The sample frequency was three samples/day at Nopigia (two during daytime and one during nighttime) and daily at Prasses. The impactor operated at a flow rate of $80 \mathrm{~m}^{3} \mathrm{~h}^{-1}$ and separated the particles into the following aerodynamic equivalent diameter $(\mathrm{Dp})$ ranges: stage 1: $>6.44 \mu \mathrm{m}$, stage 2: 2.68-6.44 $\mu \mathrm{m}$, stage 3: $1.34-2.68 \mu \mathrm{m}$, stage 4: 0.85-1.34 $\mu \mathrm{m}$, stage 5: $0.44-0.85 \mu \mathrm{m}$. Particles with diameters smaller than $0.44 \mu \mathrm{m}$ were collected on a backup Whatman-41 filter. Filters were prewashed in the laboratory with $0.1 \mathrm{M} \mathrm{HCl}$, rinsed four to five times with Milli-Q water and dried in a clean-air hood. After drying, filters were sealed individually in aluminum foil and polyethylene bags, which were opened just before use. At least $5 \%$ of the washed filters (per batch) were used as laboratory blanks, and 5\% were used as field blanks. After sampling, filters were also covered by aluminum foil, sealed in polyethylene bags, and stored in a refrigerator at $4^{\circ} \mathrm{C}$ until ion chromatographic analysis. A part of the total filter $(1 / 2$ for the stages $1-5,1 / 24$ for the final Whatman-41 filter) was extracted by sonication during $45 \mathrm{~min}$ in $20 \mathrm{~mL}$ of ultrapure water. The extraction efficiency of this method is higher than $98 \%$ for all compounds of interest; 50-100 $\mu$ l chloroform were added as a biocide in the sample extracts, and all extracts were analyzed within a week.

[7] A Dionex AS4A-SC column with ASRS-I suppressor in autosuppression mode of operation was used for the analysis of anions (chloride: $\mathrm{Cl}^{-}$; bromide: $\mathrm{Br}^{-}$; nitrate: $\mathrm{NO}_{3}{ }^{-}$, sulfate: $\mathrm{SO}_{4}{ }^{2-}$, oxalate $\mathrm{C}_{2} \mathrm{O}_{4}{ }^{2-}$ and methanesulfonate: MSA $\left(\mathrm{CH}_{3} \mathrm{SO}_{3}{ }^{-}\right)$). For the cations (sodium: $\mathrm{Na}^{+}$, ammonium: $\mathrm{NH}_{4}{ }^{+}$, potassium: $\mathrm{K}^{+}$, magnesium: $\mathrm{Mg}^{2+}$ and calcium: $\mathrm{Ca}^{2+}$ ) a CS2 column was used with a CSRS-I suppressor. The reproducibility of the measurements was better than $2 \%$, and the detection limits corresponded to $2 \mathrm{pmol} \mathrm{m}^{-3}$ of air for a mean volume of $1500 \mathrm{~m}^{3}$. Blanks for $\mathrm{CH}_{3} \mathrm{SO}_{3}{ }^{-}, \mathrm{Cl}^{-}, \mathrm{NO}_{3}{ }^{-}, \mathrm{SO}_{4}{ }^{2-}$, $\mathrm{Na}^{+}, \mathrm{NH}_{4}^{+}, \mathrm{K}^{+}, \mathrm{Mg}^{2+}, \mathrm{Ca}^{2+}$ were $<0.006,10,1.5,1.1,1.5$, $7.6,0.2,0.1$, and $0.5 \mu \mathrm{g}$, respectively. The above masses correspond to less than $2 \%$ of the minimum mass of the corresponding ion measured on the analyzed filters.

[8] At Finokalia, aerosols have been collected on Teflon filters with a sampling step of $48 \mathrm{~h}$ and a flow rate of $20 \mathrm{~L} / \mathrm{min}$. Extraction and analysis was similar to that presented above for the Whatman-41 filters. The reproducibility of these measurements was better than $2 \%$, and the detection limits for all ions corresponded to $0.04 \mathrm{nmol} / \mathrm{m}^{3}$.

\subsection{Additional Measurements}

[9] Aerosol scattering was measured at (Nopigia) at 532 $\mathrm{nm}$ using an integrating nephelometer (Radiance Research, Seattle, Washington, United States), at $7^{\circ}-170^{\circ}$ for total scattering (sigma sp; $\sigma_{\mathrm{sp}}$ ) and $90^{\circ}-170^{\circ}$ for hemispheric backscattering (sigma bsp; $\sigma_{\mathrm{bsp}}$ ).

[10] Equivalent Black Carbon (BC) mass concentrations were measured both at Nopigia and Prasses using a Particle Soot Absorption Photometer (PSAP; Radiance Research, Seattle, Washington, United States) and Magee aethalometer, respectively. Absorption of aerosol (sigma ap; $\sigma_{\text {ap }}$ ) was estimated using the relation proposed by Hansen et al. [1984] and 

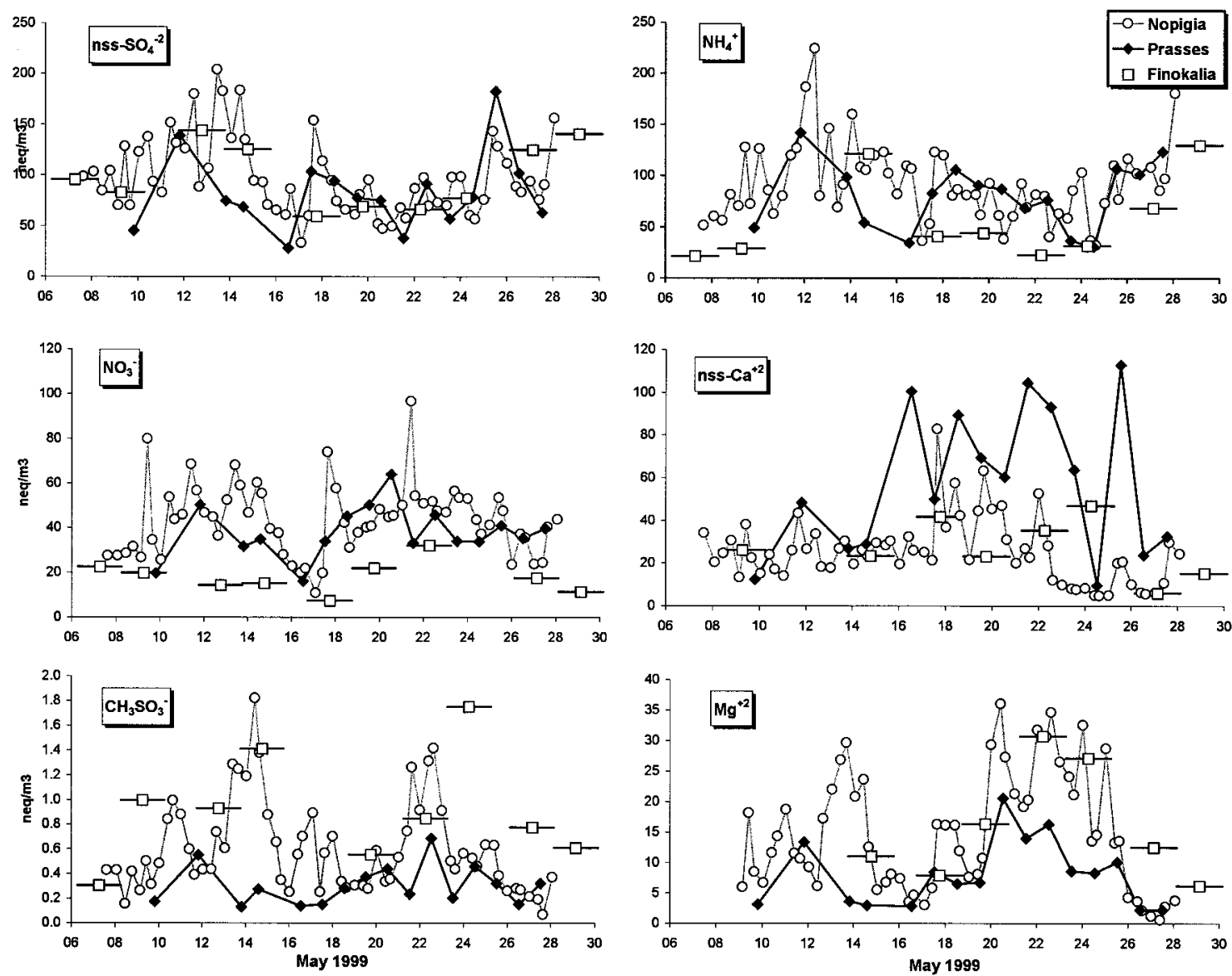

Figure 2. Variation of nss- $\mathrm{SO}_{4}{ }^{2-}, \mathrm{NO}_{3}{ }^{-}, \mathrm{CH}_{3} \mathrm{SO}_{3}{ }^{-}, \mathrm{NH}_{4}{ }^{+}, \mathrm{nss}-\mathrm{Ca}^{2+}$, and $\mathrm{Mg}^{2+}$ in neq $/ \mathrm{m}^{3}$ at the three locations during the sampling period.

optical absorption cross-sections of 10 (for PSAP) and 19 (for Magee) respectively following the recommendation of the manufactures. The inlets of the nephelometer, Particle Soot Absorption Photometer and Magee aethalometer were not heated and hence the values observed are reported for ambient relative humidity.

[11] From the above measured parameters the aerosol light extinction coefficient $\left(\sigma_{\mathrm{e}}=\sigma_{\mathrm{sp}}+\sigma_{\mathrm{ap}}\right)$ the single scattering albedo (omega; $\omega=\sigma_{\mathrm{sp}} /\left[\sigma_{\mathrm{sp}}+\sigma_{\mathrm{sp}}\right]$ ) and the hemispheric backscatter fraction $\left(\mathrm{b}=\sigma_{\mathrm{bsp}} / \sigma_{\mathrm{sp}}\right)$ can be calculated and related to direct forcing of the aerosols. However, due to software problems, no measurements of sigma bsp were available, thus chemical composition of the aerosol will be related to sigma sp, sigma ap, and omega at $532 \mathrm{~nm}$.

[12] Number and corresponding size distribution of aerosol particles were obtained at Nopigia by using a Diffusional Particle Sizer (DPS) System from TSI Company, which includes a Model 3040 Diffusion Battery and a Model 3022A Condensation Particle Counter (CPC). This system classifies and measures aerosol particles according to their size in the diameter range of 7 to $200 \mathrm{~nm}$.

[13] Aerosol optical depth measurements at $532 \mathrm{~nm}$ have been performed also at Nopigia by the Institute for Medical Physics, University of Innsbruck, using a spectroradiometer equipped with a double monochromator (Bentham DTM300, United Kingdom) with a bandwidth of $0.43 \mathrm{~nm}$ (full width at half maximum). Each scan covers the wavelength range from $290 \mathrm{~nm}$ to $600 \mathrm{~nm}$ with steps of $0.25 \mathrm{~nm}$, every $5 \mathrm{~min}$. The spectroradiometer is calibrated against a $1000 \mathrm{~W}$ halogen lamp, traceable to Physikalisch-Technische Bundesanstalt, Germany. The overall uncertainty of the calibration is estimated to be about $\pm 5 \%$. More details about the Bentham spectroradiometer and how its measurements compared to those performed by a Lidar and a ground-based sunphotometer is reported elsewhere (G. Gobi et al., unpublished manuscript, 2001).

[14] Back trajectory calculations were made using the Hybrid Single-Particle Langrangian Integrated Trajectory (HYSPLIT_4) modeling system. This public domain model (http://www.arl.noaa.gov/ready/hysplit4.html) is documented in the international literature [Draxler and Hess, 1998]. The meteorological data used in the calculations were obtained from the National Weather Service's of the National Center for Environmental Prediction (NCEP) of the United States. For the sampling periods, meteorological data both at Nopigia and Finokalia have been obtained using automatic meteorological stations installed close to the sampling devices.

\section{Results and Discussion}

\subsection{Chemical Composition}

\subsubsection{Variation of the Main Ionic Species}

[15] Figure 2 presents the variation of the main ionic nonsea-salt components, i.e., $\mathrm{nss}_{-} \mathrm{SO}_{4}{ }^{2-}, \mathrm{NO}_{3}{ }^{-}, \mathrm{CH}_{3} \mathrm{SO}_{3}{ }^{-}, \mathrm{NH}_{4}{ }^{+}$, nss- $\mathrm{Ca}^{2+}$, and $\mathrm{Mg}^{2+}$ during the whole experiment both at 
Table 1. Mean Concentrations of $\mathrm{Cl}^{-}, \mathrm{Br}^{-}, \mathrm{NO}_{3}{ }^{-}$, nss- $\mathrm{SO}_{4}{ }^{2-}, \mathrm{C}_{2} \mathrm{O}_{4}{ }^{2-}, \mathrm{CH}_{3} \mathrm{SO}_{3}{ }^{-}, \mathrm{Na}^{+}, \mathrm{NH}_{4}{ }^{+}, \mathrm{nss}^{-} \mathrm{K}^{+}, \mathrm{Mg}^{2+}$, and nss$\mathrm{Ca}^{2+}$ at the Three Locations During the Sampling Period ${ }^{\mathrm{a}}$

\begin{tabular}{|c|c|c|c|}
\hline & $\begin{array}{c}\text { Nopigia }\left(35.5^{\circ} \mathrm{N}-23.75^{\circ} \mathrm{E}\right) \\
n=62\end{array}$ & $\begin{array}{c}\text { Prasses }\left(35.35^{\circ} \mathrm{N}-23.8^{\circ} \mathrm{E}\right) \\
n=16\end{array}$ & $\begin{array}{l}\text { Finokalia }\left(35.3^{\circ} \mathrm{N}-25.7^{\circ} \mathrm{E}\right) \\
\qquad n=11\end{array}$ \\
\hline $\mathrm{Cl}^{-}$ & $84.4 \pm 46.8$ & $35.71 \pm 14.04$ & $31.8 \pm 21.7$ \\
\hline $\mathrm{Br}^{-}$ & $0.099 \pm 0.073$ & $0.029 \pm 0.021$ & $0.107 \pm 049$ \\
\hline $\mathrm{NO}_{3}{ }^{-}$ & $43.6 \pm 15.6$ & $35.1 \pm 11.7$ & $18.7 \pm 6.9$ \\
\hline nss-SO ${ }_{4}^{2-}$ & $91.7 \pm 37.1$ & $76.2 \pm 38.2$ & $83.0 \pm 34.0$ \\
\hline $\mathrm{C}_{2} \mathrm{O}_{4}{ }^{2-}$ & $4.28 \pm 1.20$ & $2.86 \pm 1.15$ & $2.81 \pm 1.05$ \\
\hline $\mathrm{CH}_{3} \mathrm{SO}_{3}^{-}$ & $0.502 \pm 0.367$ & $0.276 \pm 0.162$ & $0.811 \pm 0.467$ \\
\hline $\mathrm{Na}^{+}$ & $64.0 \pm 44.1$ & $23.0 \pm 16.2$ & $45.1 \pm 32.3$ \\
\hline $\mathrm{NH}_{4}^{+}$ & $85.1 \pm 37.1$ & $84.7 \pm 32.9$ & $36.1 \pm 40.9$ \\
\hline nss- $\mathrm{K}^{+}$ & $1.18 \pm 1.04$ & $2.07 \pm 0.90$ & $1.85 \pm 0.60$ \\
\hline $\mathrm{Mg}^{2+}$ & $13.3 \pm 9.7$ & $7.5 \pm 5.5$ & $14.4 \pm 13.0$ \\
\hline nss-Ca ${ }^{2+}$ & $24.0 \pm 15.1$ & $55.0 \pm 34.2$ & $23.5 \pm 15.3$ \\
\hline
\end{tabular}

${ }^{a}$ Concentrations are in units of neq $\mathrm{m}^{-3}$.

Nopigia and Prasses. For comparison, the data from Finokalia are also shown here. Table 1 presents the mean variation of all the ionic species measured during the period. A closer examination of the data leads to the following conclusions:

[16] $\mathrm{Nss}_{-} \mathrm{SO}_{4}{ }^{2-}$ is calculated using $\mathrm{Mg}^{2+}$ as a seawater tracer. Note that using $\mathrm{Na}^{+}$very similar results (within 10\%) are obtained. A very good agreement exists for all the sampling stations, indicating that the main factor controlling the nss$\mathrm{SO}_{4}{ }^{2-}$ distribution in the eastern Mediterranean is long-range transport rather than local sources in agreement with the conclusions presented by Mihalopoulos et al. [1997]. It is worthwhile noting the existence of a very slight gradient between the Prasses $(1030 \mathrm{~m})$ and sea level site (Nopigia) indicating an almost homogeneous distribution within the boundary layer. Nss- $\mathrm{SO}_{4}{ }^{2-}$ concentrations during Paur II were about $40 \%$ lower to that reported for Finokalia during spring 1994. Al-

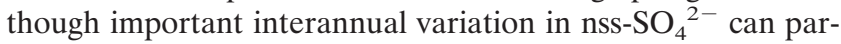
tially account for this difference [Kouvarakis et al., 2002], the data collected during spring 1994 were exclusively originating from N/NW sectors, which was not the case for the PAUR II samples (see discussion below).

[17] For nss- $\mathrm{Ca}^{2+}$ a very good agreement exists between Nopigia and Finokalia both stations situated at sea level. The nss- $-\mathrm{Ca}^{2+}$ values at Prasses are a factor of 2 higher than at sea level (Table 1). Prasses is located at $1030 \mathrm{~m}$ of altitude and thus can be more affected by the dust layer situated between 2 and $3 \mathrm{~km}$ above the ground (see further discussion on air mass origin). The nss- $\mathrm{Ca}^{2+}$ levels observed at Nopigia and Finokalia are in very good agreement with the values reported for Finokalia during spring 1994 [Mihalopoulos et al., 1997].

[18] For $\mathrm{NO}_{3}{ }^{-}$and $\mathrm{NH}_{4}{ }^{+}$a very good agreement exists between the values observed at Nopigia and Prasses. However, the observations at Finokalia during May 1999 are a factor of 2 lower than at the other sites. As mentioned in the experimental part, different filter media has been used for the aerosol sampling at Paur II sites and at Finokalia. It is well known that $\mathrm{HNO}_{3}$ can be adsorbed on cellulose paper media (especially on the coarse mode) inducing a positive artifact. Taking into account that $\mathrm{HNO}_{3}$ levels at Finokalia are comparable to $\mathrm{NO}_{3}{ }^{-}$[Kouvarakis et al., 2001], this fact could explain the difference observed between the West and East Cretan stations. However, the $\mathrm{NO}_{3}{ }^{-}$and $\mathrm{NH}_{4}{ }^{+}$values observed at Finokalia are in good agreement with the values reported by $\mathrm{Mi}$ halopoulos et al. [1997] during spring 1994-1995. Taking into account that these measurements were performed using What- man-41 as sampling media, it indicates that the difference of factor of 2 observed in the $\mathrm{NO}_{3}{ }^{-}$and $\mathrm{NH}_{4}{ }^{+}$values between the Finokalia and the PAUR II samples could be mainly due to local sources origin than purely to sampling artifacts.

[19] Finally, for MSA which is a product of the atmospheric oxidation of the gaseous DMS $\left(\mathrm{CH}_{3} \mathrm{SCH}_{3}\right)$ produced in seawater as a result of the interactions between phytoplankton, zooplankton, and bacteria [Belviso et al., 1990; Groene, 1995], no significant difference is observed between the data measured at the two sea level sites indicating a quasi homogeneous distribution of DMS in the area around Crete, in agreement with the results of Bardouki [2000] and Kouvarakis and Mihalopoulos [2002]. Note also the existence of a gradient in the MSA levels between Nopigia and Prasses in line with the short lifetime of DMS in the atmosphere over the studied area varying from few minutes during nighttime to few hours during daytime [Kouvarakis and Mihalopoulos, 2002].

\subsubsection{Factors Controlling the Variation of the Main Ionic Species}

[20] Detailed meteorological conditions during the campaign are described by D. Melas et al. (unpublished manuscript 2001). Figure 3 presents 5 -day back trajectories (at two altitudes; 1 and $3 \mathrm{~km}$ ) for the main air masses origin observed during the campaign. From the beginning of the experiment and until May 15 the air masses originated from the NW sector, turning slowly to the west sector until May 17. From 18 May an intrusion of Saharan dust was clearly seen at $3 \mathrm{~km}$ of altitude, whereas at $1 \mathrm{~km}$ the winds were still of NW origin. This situation continued until 21 May when air masses were turning to the South sector in both altitudes, until 23 May when a situation similar to 18 May was observed. After that date and until the end of the campaign, the air masses turned from the west to the NW sectors (25 May) and finally to the north sector (27 May). This change in air mass origin and especially the period under the influence of dust is clearly seen in Figure 4 presenting the variation of nss- $\mathrm{Ca}^{2+}$ and nss- $\mathrm{SO}_{4}{ }^{2-}$ as well as their ratio during the experiment. Indeed, the ratio during the nondusty period was always low ranging from $0.08-0.3$. Then from 17 May it increases dramatically to reach values of the order of 0.9 on 21 May clearly associated with the transport from the southern sector as discussed before and presented in Figure 3.

[21] Using these 5-day back trajectories, the main ionic species have been classified according to the major wind sec- 

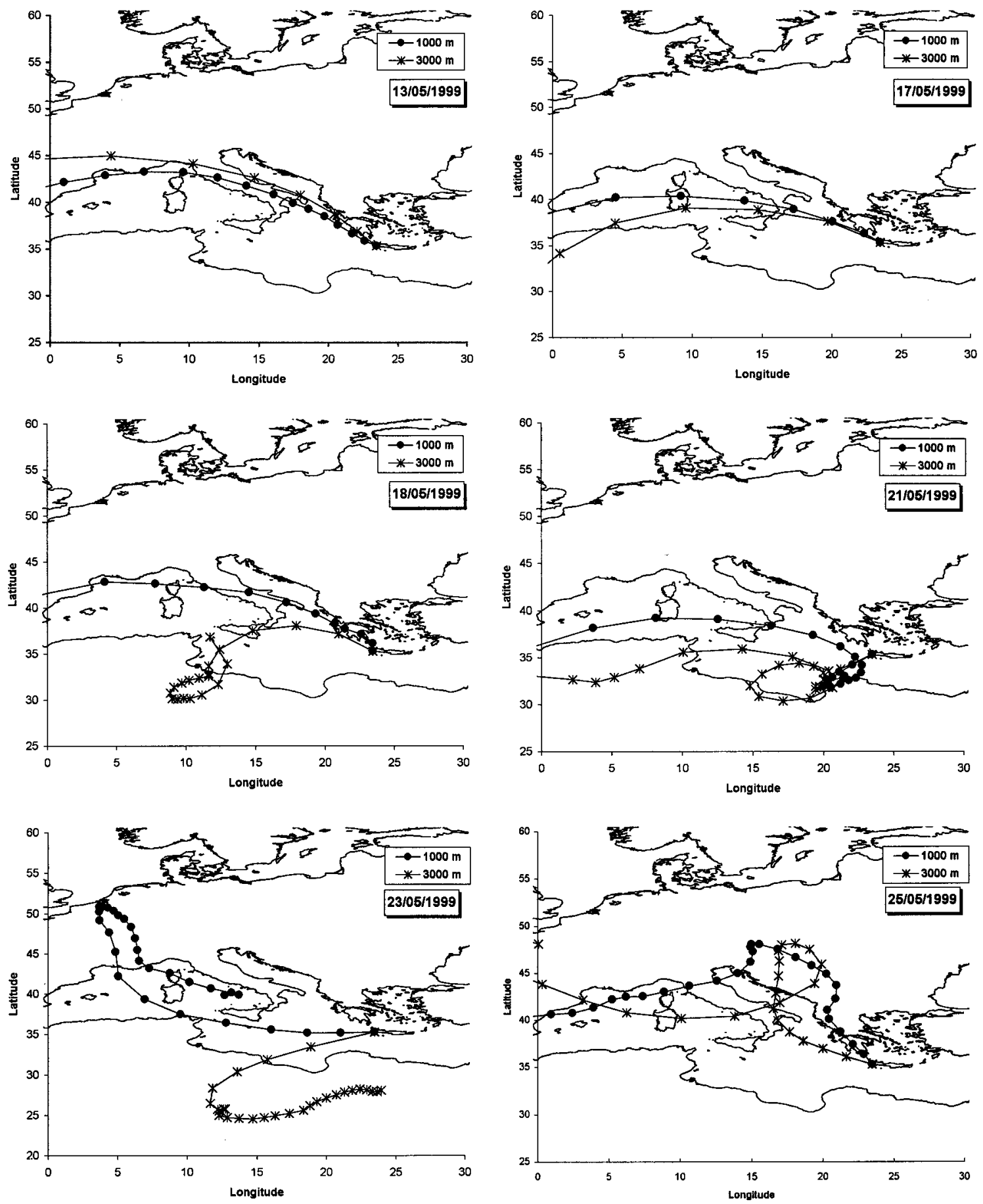

Figure 3. Trajectory analysis of the air masses arriving at Nopigia during the period May 13-25.

tors defined by Mihalopoulos et al. [1997]. The results are depicted in Figure 5 and concern only the data obtained at Nopigia because this data set contains sufficient number of samples for accurate statistical analysis. Note, however, that similar trends have been found in Prasses data set. From the results depicted in Figure 5 it is clear that both nss- $\mathrm{SO}_{4}{ }^{2-}$ and $\mathrm{NH}_{4}{ }^{+}$present the same behavior as a function of air masses origin and their concentration are following the tendency $\mathrm{S}<\mathrm{W}<\mathrm{N}<\mathrm{NW}$ in agreement with the conclusions of Mihalopoulos et al. [1997]. For nss-Ca ${ }^{2+}$ the higher values are associated with the South sector. The relatively high values ob- served under the west and NW origin could be attributed to local influence (air masses are traveling over a part of land before reaching the station; see Figure 1). Finally, no clear tendency is observed for the $\mathrm{NO}_{3}{ }^{-}$values, with the higher values occurred under NW and South sectors influence. Absorption of acidic gases like $\mathrm{HNO}_{3}$ on basic particles like dust as proposed by Dentener et al. [1996] could account for this tendency (see also the discussion below on size distribution).

[22] Apart from air masses origin, meteorological factors can also account for the variation in the concentration of species, especially for those originated from seawater. Figure 6 


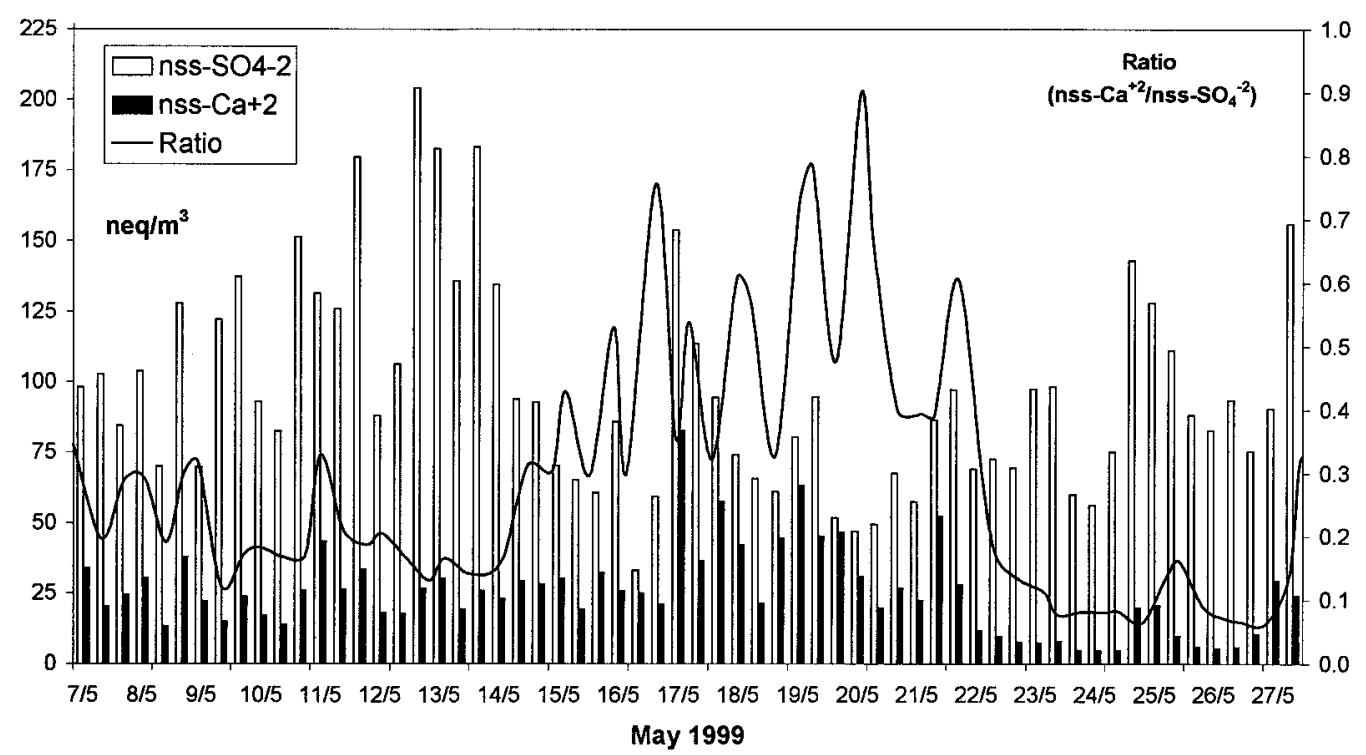

Figure 4. Variation of nss- $\mathrm{SO}_{4}{ }^{2-}$, nss- $\mathrm{Ca}^{2+}$, and their ratio at Nopigia during the sampling period.

presents the variation of MSA and $\mathrm{Mg}^{2+}$ as a function of wind speed. In most cases these compounds follow the variation of wind speed indicating local rather than long-range transport origin (oxidation of DMS for the MSA, sea spray for $\mathrm{Mg}^{2+}$ ).

\subsubsection{Interspecies Correlation}

[23] Figure 7 presents the sum of cations as a function of the sum of anions and for the aerosol samples collected both at Nopigia and Prasses. For comparison the 1:1 line is also drawn. Despite the fact that we have experienced various air masses origins during the experiment a good agreement exists between the sum of the anions and the cations, indicating almost complete ionic chemical characterization of the aerosol.
[24] Figures $8 \mathrm{a}$ and $8 \mathrm{~b}$ present two among the most characteristic relationships observed during the experiment: (1) that of $\mathrm{Na}^{+}$and $\mathrm{Mg}^{2+}$ (Figure 8a) and (2) that of $\mathrm{NH}_{4}{ }^{+}$and nss- $\mathrm{SO}_{4}{ }^{2-}$ (Figure $8 \mathrm{~b}$ ). The first relation indicates that both compounds mainly originate from seawater since the slope of their regression $(0.21)$ is close to that reported for seawater (0.23). The second relationship indicates that $\mathrm{NH}_{4}{ }^{+}$can neutralize nss- $\mathrm{SO}_{4}{ }^{2-}$ both at Prasses and Nopigia. The slope of the regression of 1 indicates almost complete neutralization of $\mathrm{H}_{2} \mathrm{SO}_{4}$ forming mainly $\left(\mathrm{NH}_{4}\right)_{2} \mathrm{SO}_{4}$.

[25] Finally, of particular interest is the halogen behavior. Figures $9 \mathrm{a}$ and $9 \mathrm{~b}$ present the variation of bromide and chloride fractional deficit/excess during thee experiment as a function of the net acidity. Net acidity has been defined as the
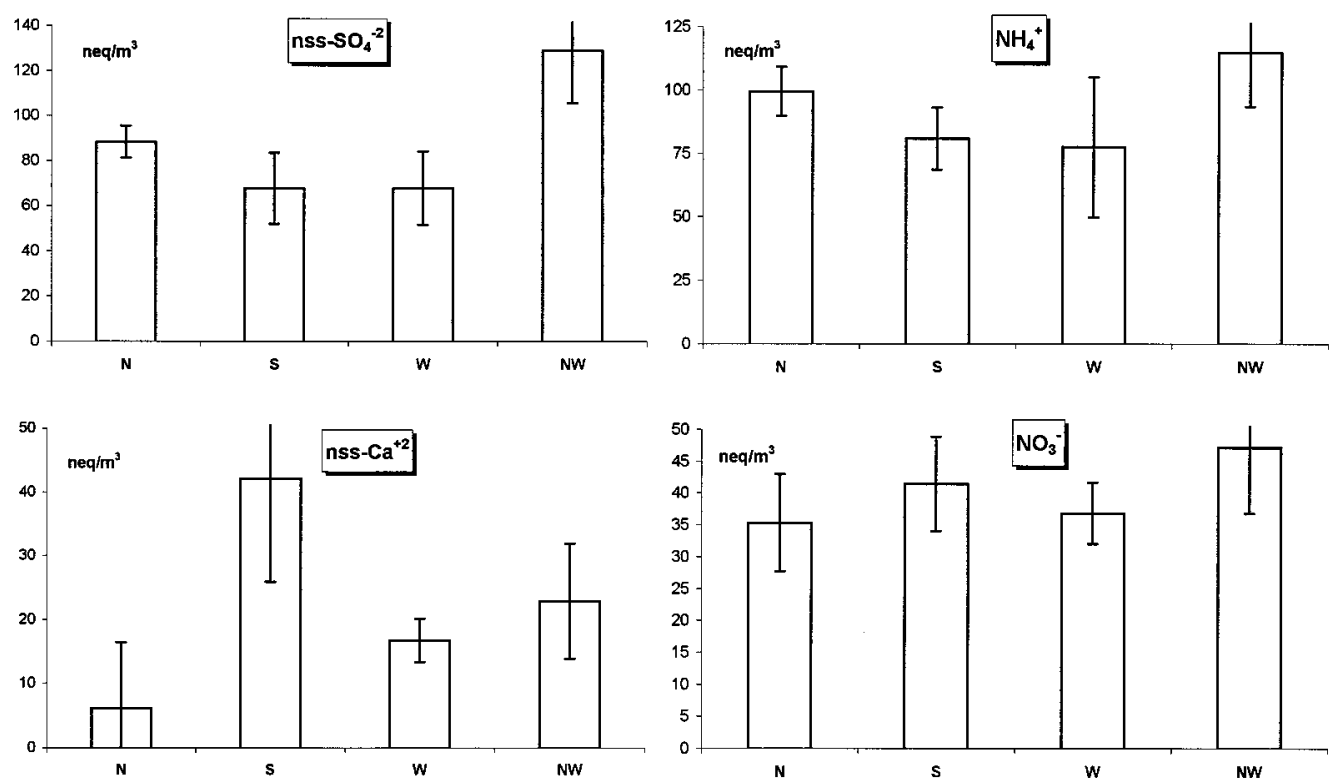

Figure 5. Per sector variation of nss- $\mathrm{SO}_{4}{ }^{2-}, \mathrm{NO}_{3}{ }^{-}, \mathrm{nss}-\mathrm{Ca}^{2+}$, and $\mathrm{NH}_{4}{ }^{+}$(in neq $/ \mathrm{m}^{3}$ ) at Nopigia during the sampling period. 

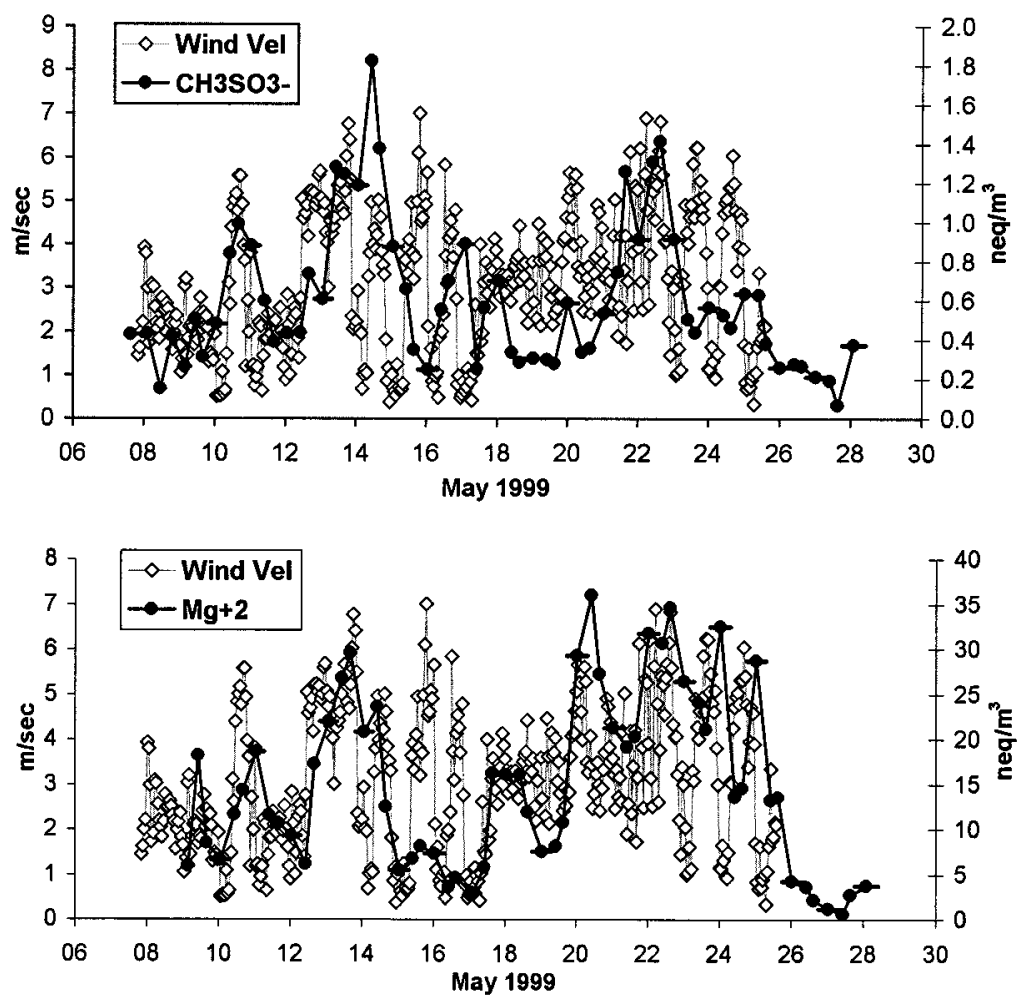

Figure 6. Variation of $\mathrm{Mg}^{2+}$ and MSA at Nopigia as a function of wind speed during the sampling period.

difference between the acidic anions (nss- $\mathrm{SO}_{4}{ }^{2-}+\mathrm{NO}_{3}{ }^{-}+$ $\mathrm{CH}_{3} \mathrm{SO}_{3}{ }^{-}$) minus the basic cations (nss- $\mathrm{Ca}^{2+}+\mathrm{NH}_{4}{ }^{+}+$nss$\mathrm{K}^{+}$) following Ayers et al. [1999]. For both halogens a net anticorrelation between the halogen deficit and the acidity exists denoting an important role of acid catalysis to the dehalogenation process. A clear deficit has been observed only under north and NW air masses origin. In west and SW air masses, slight excess is observed probably due to adsorption of these acidic gases $(\mathrm{HBr}$ and $\mathrm{HCl})$ on alkaline particles. In addition, the fractional $\mathrm{Br}$ deficit was higher compared to $\mathrm{Cl}$ deficit, in agreement with the model calculations [Keene et al., 1998] and the observations at Cape-Grim [Ayers et al., 1999]. Indeed, during the whole experiment the median values for $\mathrm{Cl}^{-}$and $\mathrm{Br}^{-}$deficits were 8 and $55 \%$, respectively.

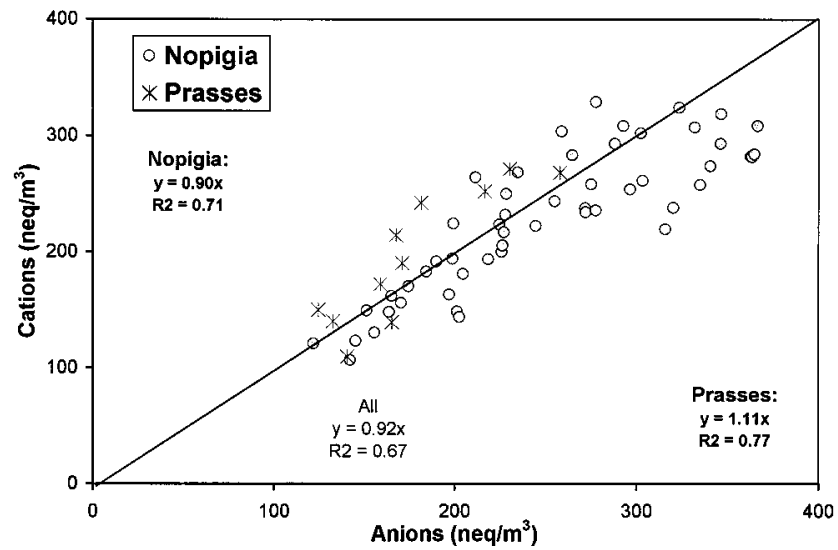

Figure 7. Comparison between the sum of anions and cations measured during the experiment both at Nopigia and Prasses.

\subsubsection{Particle Size Distributions}

[26] Figure 10 presents the particle size distribution of seven selected species denoting sea salt $\left(\mathrm{Na}^{+}\right)$, dust (nss$\mathrm{Ca}^{2+}$ ), biogenic $\left(\mathrm{NH}_{4}^{+}, \mathrm{MSA}\right)$, and anthropogenic origin (nss$\mathrm{SO}_{4}{ }^{2-}, \mathrm{NO}_{3}{ }^{-}, \mathrm{H}^{+}$(corresponding to the $\mathrm{H}^{+}$concentration of
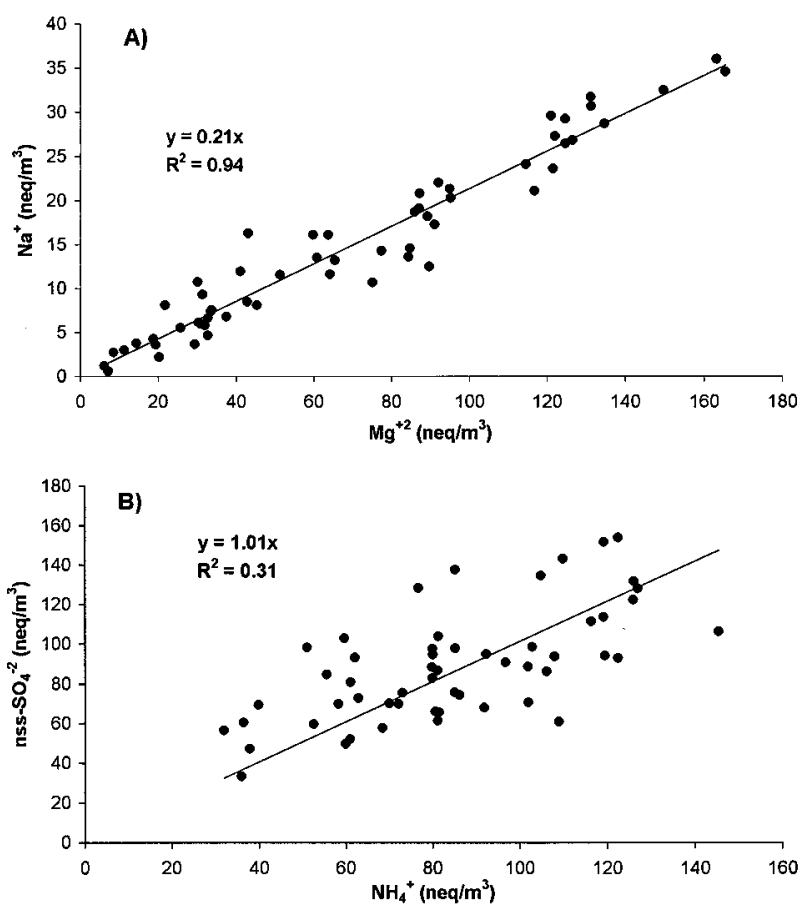

Figure 8. Correlation between (a) $\mathrm{Na}^{+}$and $\mathrm{Mg}^{2+}$ and (b) $\mathrm{NH}_{4}{ }^{+}$and nss-SO ${ }_{4}^{2-}$ at Nopigia during the experiment. 

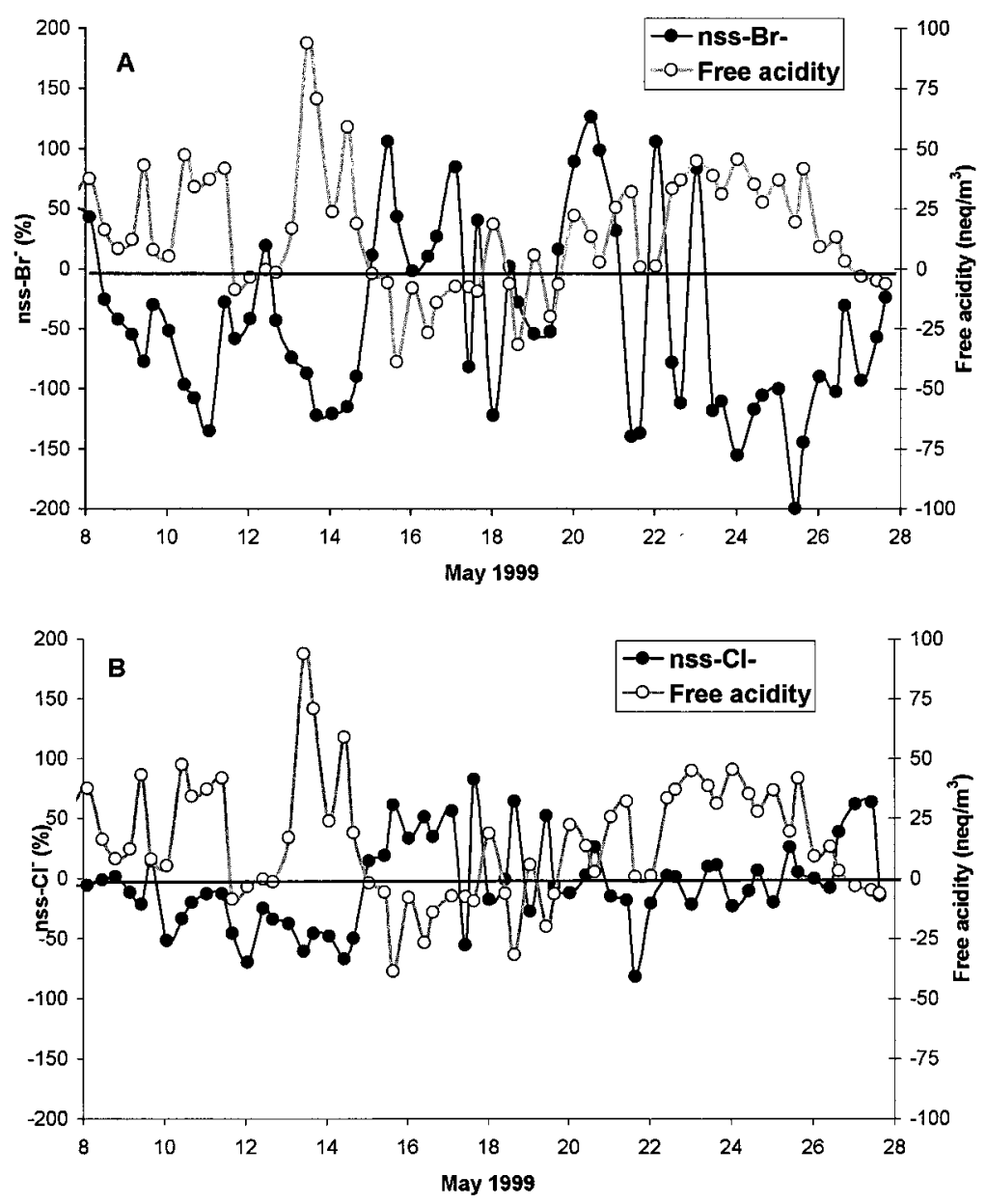

Figure 9. Variation of (a) $\mathrm{Br}^{-}$and (b) $\mathrm{Cl}^{-}$deficit/excess at Nopigia during the campaign and as a function of free acidity (nss- $\left.\mathrm{SO}_{4}{ }^{2-}+\mathrm{NO}_{3}{ }^{-}+\mathrm{CH}_{3} \mathrm{SO}_{3}{ }^{-}\right)-\left(\mathrm{nss}-\mathrm{Ca}^{2+}+\mathrm{NH}_{4}{ }^{+}+\mathrm{nss}-\mathrm{K}^{+}\right)$.

the water extract of the filter)). In agreement with most aerosol size distributions reported in the literature, nss$\mathrm{SO}_{4}{ }^{2-}, \mathrm{NH}_{4}{ }^{+}, \mathrm{H}^{+}$, and MSA present their maximum in the fine mode. On the other hand, $\mathrm{Na}^{+}, \mathrm{nss}-\mathrm{Ca}^{2+}$, and $\mathrm{NO}_{3}{ }^{-}$ present their maximum in the first stages as they result either from direct emission or adsorption of $\mathrm{HNO}_{3}$ on seasalt particles. Of particular interest is the influence of air mass origin on size distribution of main anions and cations shown in Table 2. In this table we mainly focus on ionic species existing, in aerosol phase, in equilibrium with its gaseous phase precursor, i.e., nss- $\mathrm{SO}_{4}{ }^{2-}, \mathrm{NO}_{3}{ }^{-}, \mathrm{NH}_{4}{ }^{+}$, MSA, $\mathrm{C}_{2} \mathrm{O}_{4}{ }^{2-}$, and $\mathrm{Br}^{-}$. As it can be seen, with the exception of $\mathrm{NH}_{4}{ }^{+}$for which no clear tendency exists, for all the other species the South sector presents concentrations much higher in the coarse mode compared to the fine. The above tendency, which follows the $\mathrm{pH}$ of the aerosols, i.e., acidic in the north sector, basic in the south sector, can explain the absence of clear sector preference for $\mathrm{NH}_{4}{ }^{+}$. On the other hand, the clear enrichment observed in the coarse mode under South sector influence for all the other ions (Table 2) corroborates the hypothesis presented by Dentener et al. [1996] of possible adsorption of acidic gases on alkaline medium such as dust. Note also the important depletion of $\mathrm{Br}^{-}$from coarse particles in aerosols originating from the $\mathrm{N}$ sector in agreement with the previous discussion on Br deficit.

\subsection{Physical and Optical Parameters}

\subsubsection{Time Series}

[27] Figure 11 presents time series of the following parameters: $\sigma_{\mathrm{sp}}$ measured with the nephelometer at $532 \mathrm{~nm}$, black carbon equivalent concentrations from the Magee aethalometer, single-scattering albedo $\omega, \mathrm{CN}$ particle number concentration in their corresponding geometric diameter in the range (7-200 nm), and aerosol optical depth. Table 3 gives the arithmetic mean, the median, and the range of the above mentioned parameters.

[28] Aerosol scattering coefficient ranges from 2-51 $\mathrm{M} \mathrm{m}^{-1}$ during the experiment (Figure 11a; average equal to 23.3) in agreement with the average background scattering coefficient of $25 \mathrm{M} \mathrm{m}^{-1}$ observed by Ichoku et al. [1999] in a Mediterranean arid environment. For comparison purposes, separation between dusty and nondusty periods has been performed on the basis of back trajectory calculations. Surprisingly, no important difference was observed between dusty and nondusty periods indicating a comparable contribution of anthropogenic aerosols and dust at an area far from their sources since Crete is located at about 700 to $1000 \mathrm{~km}$ distance from Sahara, NW Europe, and Balkans, respectively, where the main sources are expected. The lowest values of aerosol scattering are observed from May 16 to 18 associated with transport from the west/ 

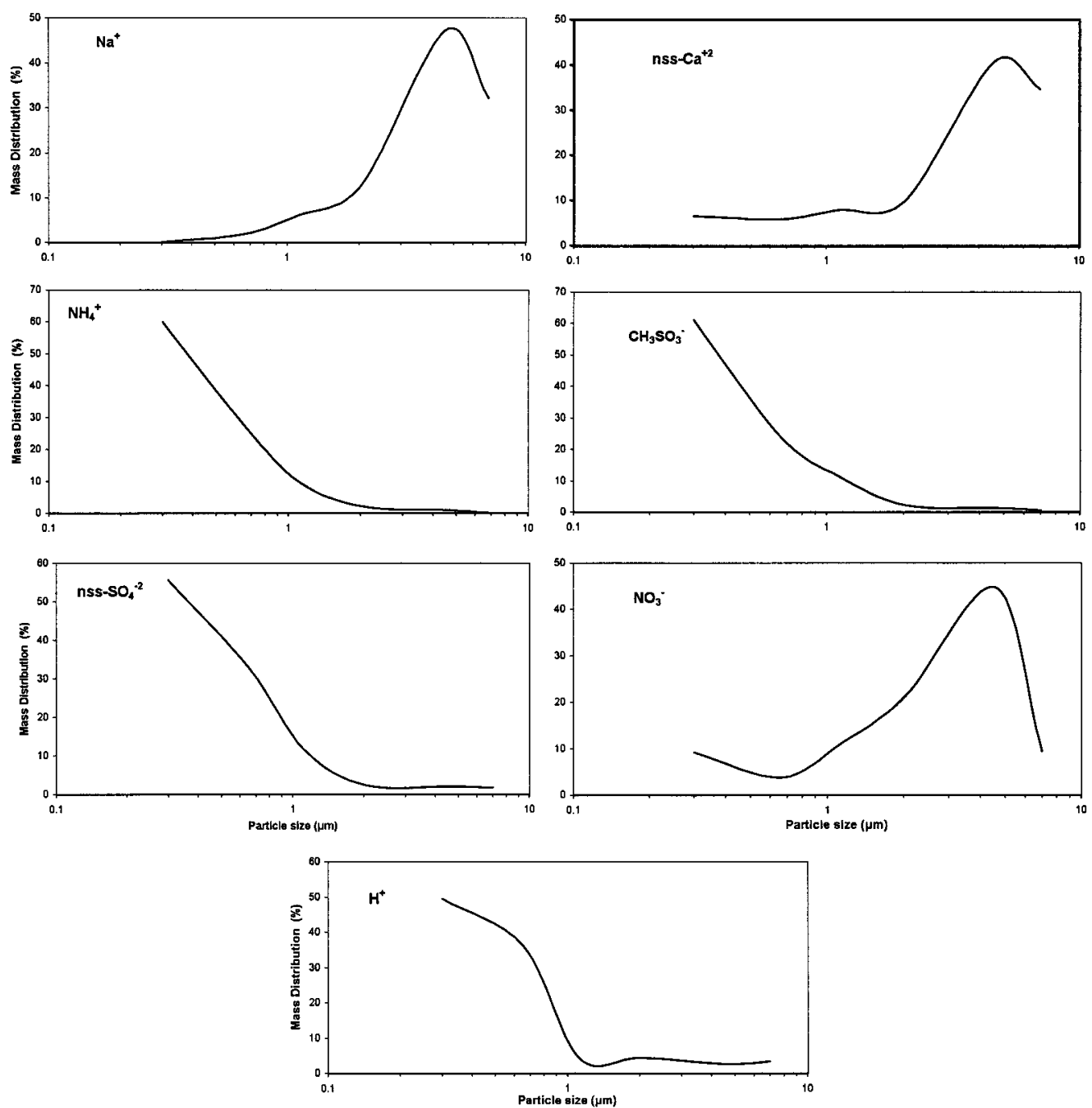

Figure 10. Particle size distribution of seven selected species of sea salt $\left(\mathrm{Na}^{+}\right)$, dust $\left(\mathrm{nss}-\mathrm{Ca}^{2+}\right)$, anthropogenic (nss- $\mathrm{SO}_{4}{ }^{2-}, \mathrm{NO}_{3}{ }^{-}, \mathrm{H}^{+}$), and biogenic origin $\left(\mathrm{NH}_{4}{ }^{+}, \mathrm{MSA}\right.$ ) both at Nopigia and Prasses.

marine sector and consist the background of scattering coefficient for the area.

[29] Aitken particle concentration as well as black carbon where used as indicators of anthropogenic pollution (Figures $11 \mathrm{~b}, 11 \mathrm{~d}$, and 11f). Aiken nuclei varied from $775 \mathrm{~cm}^{-3}$ up to $8000 \mathrm{~cm}^{-3}$. The high values observed during three cases are probably due to local pollution events. On the basis of the trajectory analysis presented in Figure 3, the higher Aitken

Table 2. Coarse to Fine Ratio of $\mathrm{NH}_{4}^{+}, \mathrm{Cl}^{-}, \mathrm{Br}^{-}, \mathrm{NO}_{3}{ }^{-}$, nss- $\mathrm{SO}_{4}{ }^{2-}, \mathrm{C}_{2} \mathrm{O}_{4}{ }^{2-}$, and $\mathrm{CH}_{3} \mathrm{SO}_{3}{ }^{-}$Concentrations at Nopigia Under Northern and Southern Winds

\begin{tabular}{lcc}
\hline & \multicolumn{2}{c}{ Ratio (Coarse/Fine) } \\
\cline { 2 - 3 } & North & South \\
\hline $\mathrm{NH}_{4}{ }^{+}$ & 0.16 & 0.17 \\
$\mathrm{Cl}^{-}$ & 0.35 & 2.28 \\
$\mathrm{Br}^{-}$ & 0.19 & 2.09 \\
$\mathrm{NO}_{3}{ }^{-}$ & 1.16 & 3.54 \\
$\mathrm{nss}^{-} \mathrm{SO}_{2}{ }^{2-}$ & 0.05 & 0.11 \\
$\mathrm{C}_{2} \mathrm{O}_{4}{ }^{2-}$ & 0.34 & 0.47 \\
$\mathrm{CH}_{3} \mathrm{SO}_{3}{ }^{-}$ & 0.04 & 0.12 \\
\hline
\end{tabular}

nuclei numbers are associated with transport from the N/NW sectors and the lowest with transport from the south and the west sectors. Of particular interest is the variation of the geometric diameter of Aitken nuclei during the campaign. With the exception of the low geometric diameters (around 20nm) observed during local pollution events due to fresh locally produced particles the majority of the cases were associated with a geometric diameter in the range of 40-80nm (median equal to $61 \mathrm{~nm}$ ). A closer look at the aerosol size distribution shows the existence of a monomodal distribution independently of the air masses origin, indicating aged long-range transported aerosol rather than locally produced.

[30] Black carbon (BC) concentrations range from 0.04 to $0.49 \mu \mathrm{g} / \mathrm{m} 3$ (median equal to 0.19 ). In the following discussion only the data obtained at Prasses site will be considered since Nopigia data are suspected to be influenced by local sources. The observed BC values are similar to those reported by Ichoku et al. [1999] and to those measured at Finokalia in May during the $1997-2000$ period $(0.26 \mu \mathrm{g} / \mathrm{m} 3$ (H. Cachier and N. Mihalopoulos, unpublished results, 2000)). Black carbon follows quite well the Aitken nuclei $(\mathrm{CN})$ variation; however, no significant correlation between these two parameters exists 

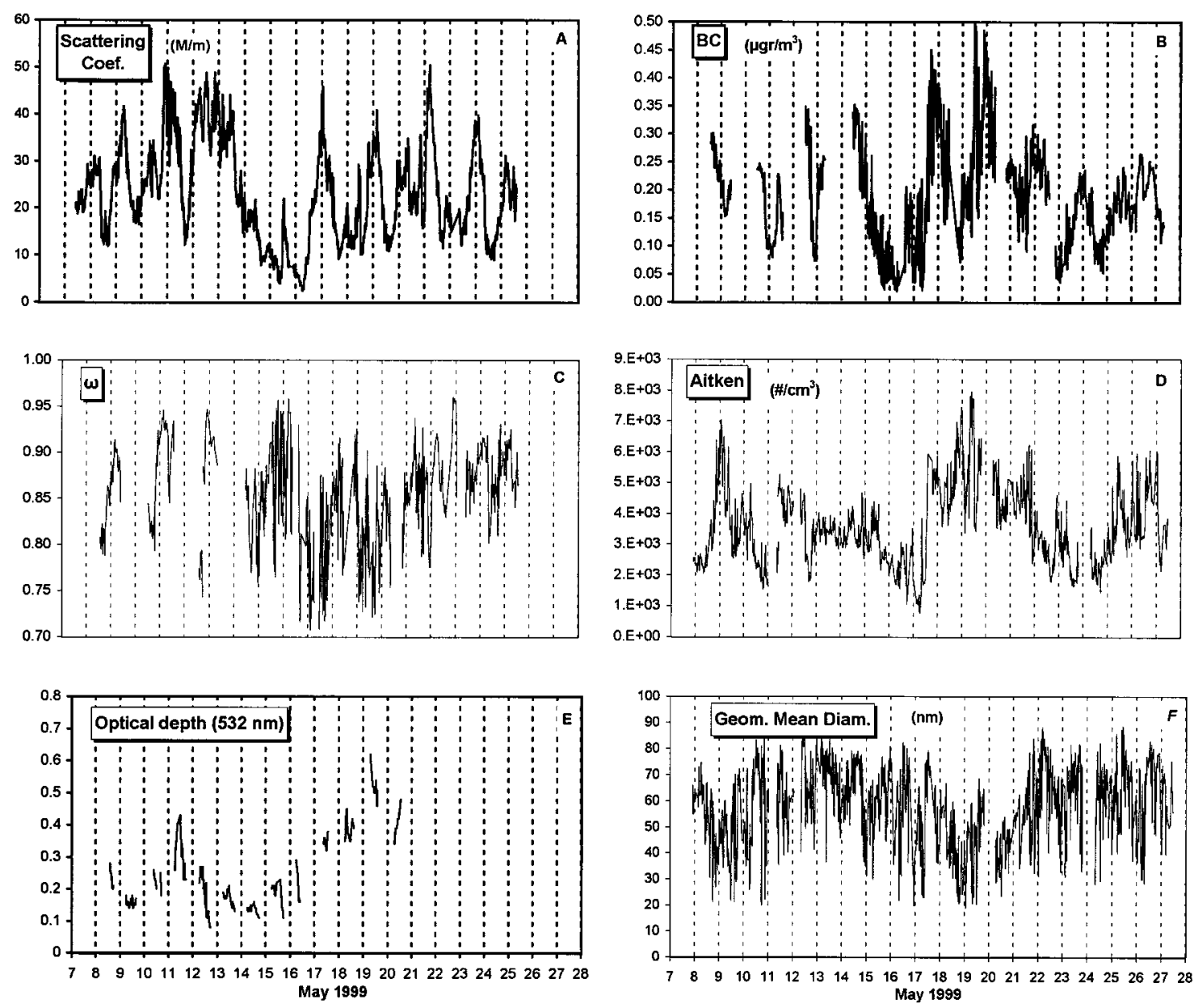

Figure 11. Time series plots of (a) $\sigma_{\mathrm{sp}}$ measured with the nephelometer at $532 \mathrm{~nm}$, (b) black carbon equivalent concentrations from the Magee aethalometer, (c) single-scattering albedo $\omega,(\mathrm{d}, \mathrm{f}) \mathrm{CN}$ particle number concentration in their corresponding geometric diameter in the range $(7-200 \mathrm{~nm})$, and (e) aerosol optical depth.

probably due to their different lifetime (days for BC, few hours for $\mathrm{CN}$ ).

[31] In modeling aerosol radiative forcing, "the key parameter governing the amount of cooling versus heating is the single-scattering albedo, $\omega$ " [Seinfeld and Pandis, 1998, pp. 1147-1152]. This parameter was computed from the absorption coefficients (from the Prasses aethalometer measurements) and the nephelometer scattering coefficients both at $532 \mathrm{~nm}$ wavelength. During this experiment, $\omega$ ranges from 0.91 when air masses are originating from the west sector (clean marine sector) to 0.81 under N/NW flow (anthropogenic sector; Figure 11c). The values observed during dust event (0.87) falls in the range of the values reported by Moulin et al. [1997a] and Hess et al. [1998] as representative of various desert dust aerosols models.

[32] Finally, Figure 11e presents the variation of optical depth (O.D) as measured during the experiment using a spectroradiometer equipped with a double monochromator (Bentham DTM300, United Kingdom). Optical depth ranges from 0.08 to 0.75 in the range of the values reported by Moulin

Table 3. Arithmetic Mean, Standard Deviation, Median, Range, and Number of Measurements of Black Carbon Equivalent Concentrations, Aerosol Scattering Coefficient, Single-Scattering Albedo $\left(\sigma_{\mathrm{sp}}\right)$ Aerosol Optical Depth and CN Particle Number Concentration and Their Corresponding Geometric Diameter During the Sampling Period ${ }^{\mathrm{a}}$

\begin{tabular}{|c|c|c|c|c|c|c|}
\hline & $\underset{\mathrm{m}^{3}}{\mathrm{BC}, \mu \mathrm{g} /}$ & $\begin{array}{c}\text { Scattering } \\
M / \mathrm{m}\end{array}$ & $\omega$ & O.D. & $\underset{\mathrm{cm}^{3}}{\text { Aitken, number/ }}$ & $\begin{array}{c}\text { G.D., } \\
\mathrm{nm}\end{array}$ \\
\hline Average & 0.19 & 23.3 & 0.85 & 0.28 & 3470 & 59 \\
\hline Median & 0.19 & 22.2 & 0.86 & 0.22 & 3310 & 61 \\
\hline s.d. & 0.09 & 10.2 & 0.05 & 0.14 & 1220 & 15 \\
\hline Maximum & 0.49 & 50.7 & 0.96 & 0.75 & 7970 & 89 \\
\hline Minimum & 0.04 & 2.4 & 0.71 & 0.08 & 775 & 19 \\
\hline Number $(n)$ & 768 & 2348 & 768 & 1782 & 1219 & 1219 \\
\hline
\end{tabular}

${ }^{\mathrm{a}}$ For the locations of the measurements, refer to the text. 

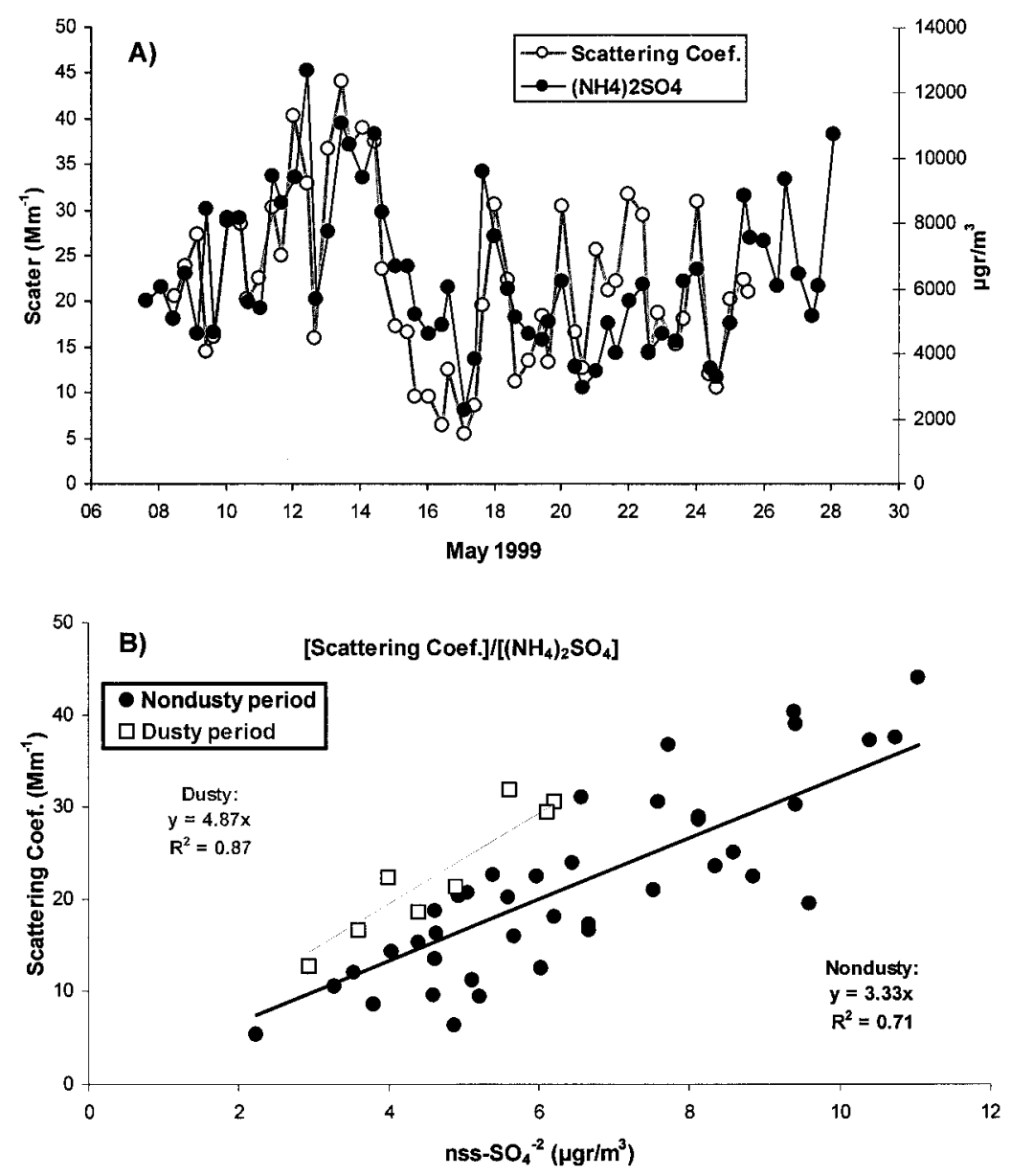

Figure 12. (a) Times series of measurements of aerosol scattering coefficient and $\left(\mathrm{NH}_{4}\right)_{2} \mathrm{SO}_{4}$ at Nopigia during the campaign. (b) Correlation between $\left(\mathrm{NH}_{4}\right)_{2} \mathrm{SO}_{4}$ and $\sigma_{\mathrm{sp}}$ during the dusty and nondusty periods.

et al. [1997b] for the Mediterranean area, and the highest values are clearly associated with dust events as it can be seen from the trajectory analysis (Figure 3).

\subsubsection{Relation of Physical and Optical Properties with Chemical Composition}

[33] Figure 12a presents the variation of scattering coefficient $\left(\sigma_{\mathrm{sp}}\right)$ with $\left(\mathrm{NH}_{4}\right)_{2} \mathrm{SO}_{4}$ during the campaign. For both parameters a separation between the dusty and nondusty periods has been performed. The $\left(\mathrm{NH}_{4}\right)_{2} \mathrm{SO}_{4}$ was choosing because its mass scattering efficiency is a value used in modeling the direct effect of aerosols on climate. To calculate its mass scattering efficiency, the mass of $\left(\mathrm{NH}_{4}\right)_{2} \mathrm{SO}_{4}$ measured during the campaign as a function of $\left(\sigma_{\mathrm{sp}}\right)$ is reported in Figure 12b. Values of 3.3 and $4.9 \mathrm{~m}^{2} \mathrm{~g}^{-1}$ have been derived for both the dusty and nondusty periods, respectively, using the slopes of the regressions. The above values are in good agreement with the values of $3.6 \pm 2.3$ and $3.8 \pm 0.8$ reported by Maring et al. [2000] for Izana, located at the same latitude with Crete and the value of $5 \pm 2$ used in climate forcing estimates [Charlson et al. 1991].

[34] Optical depth variation has been compared with all the main ionic constituents measured during the experiment; however, a significant correlation was found only with nss-Ca ${ }^{2+}$ (Figures 13a and 13b). A possible explanation for this correlation is that nss- $\mathrm{Ca}^{2+}$ values measured in Crete as well as at other locations of the eastern Mediterranean compares signif- icantly with the total A1 concentration concurrently measured $\left(r^{2}=0.55 ; n=600\right.$ (N. Mihalopoulos et al., unpublished data, 2000)). Thus the significant correlation between $\mathrm{nss}^{-\mathrm{Ca}^{2+}}$ and O.D simply indicates the role of dust in regulating the O.D. above the area.

\section{Conclusions}

[35] On the basis of the measurements of physical, optical, and chemical properties of aerosols performed during a month period at coastal areas in Crete we can draw the following conclusions:

1. Non-sea-salt sulfate $\left(\mathrm{nss}-\mathrm{SO}_{4}{ }^{2-}\right)$, nitrate $\left(\mathrm{NO}_{3}{ }^{-}\right)$, non-sea-salt calcium (nss- $\mathrm{Ca}^{2+}$ ), and $\mathrm{NH}_{4}{ }^{+}$have been identified as the main ionic components of the aerosols. For nss$\mathrm{SO}_{4}{ }^{2-}$ a very good agreement exists for all the sampling stations, indicating that the main factor controlling the nss- $\mathrm{SO}_{4}{ }^{2-}$ distribution in the eastern Mediterranean is long-range transport rather than local sources.

2. Air mass origin was identified as the main factor controlling the variation of the above ions as well as their particle size distribution. $\mathrm{Nss}_{-} \mathrm{SO}_{4}{ }^{2-}$ and $\mathrm{NH}_{4}{ }^{+}$present the same behavior as a function of air masses origin, and their concentration in the main wind sectors is following the tendency $\mathrm{S}<\mathrm{W}<\mathrm{N}<\mathrm{NW}$. For nss- $\mathrm{Ca}^{2+}$ the higher values are associated with the South sector. Finally, for the $\mathrm{NO}_{3}{ }^{-}$values, no clear tendency is observed when the higher values occurred under 

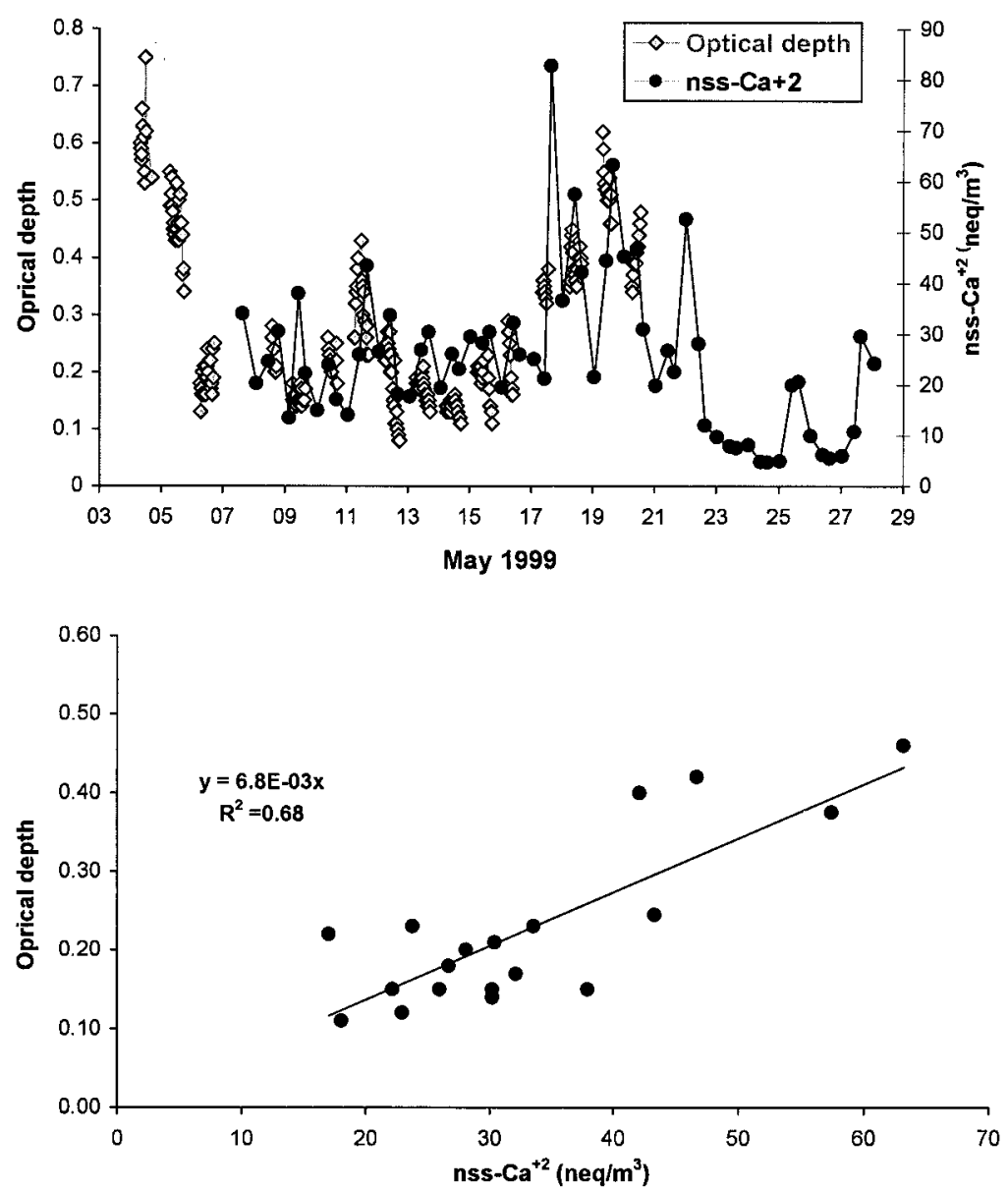

Figure 13. (a) Times series of measurements of optical depth (O.D) and nss- $\mathrm{Ca}^{2+}$ at Nopigia during the campaign. (b) Correlation between nss- $\mathrm{Ca}^{2+}$ and (O.D) during the experiment.

NW and South sectors' influence. Absorption of acidic gases like $\mathrm{HNO}_{3}$ on basic particles like dust as proposed by Dentener et al. [1996] could account for this tendency.

3. A clear deficit has been observed for both chloride and bromide with a fractional deficit closely dependent to the net acidity. For both halogens a net anticorrelation between the halogen deficit and the acidity exists denoting an important role of acid catalysis to the dehalogenation process. The fractional $\mathrm{Br}$ deficit was higher compared to $\mathrm{Cl}^{-}$deficit, in agreement with the model calculations [Keene et al., 1998] since during the whole experiment the median values for $\mathrm{Cl}^{-}$and $\mathrm{Br}^{-}$deficits were 8 and $55 \%$, respectively.

4. Aerosol scattering coefficient ranges from 2-51 M $\mathrm{m}^{-1}$ with no significant difference between dusty and nondusty periods. Significant correlations have been observed between $\left(\mathrm{NH}_{4}\right)_{2} \mathrm{SO}_{4}$ mass measured during the campaign and aerosol scattering coefficient indicating the key role of $\left(\mathrm{NH}_{4}\right)_{2} \mathrm{SO}_{4}$ in determining the radiative forcing of the eastern Mediterranean area. It is worthwhile note that the organic content of the aerosols was completely ignored in this study. Although the measured ionic part contributes up to $50 \%$ of the total aerosol mass [Kavouras et al., 1996; H. Bardouki et al., Chemical composition of size resolved atmospheric aerosols in the eastern Mediterranean during summer and winter, submitted to Atmospheric Environment, 2002], the organic content of the aerosols could have also contributed to the observed aerosol scattering.

5. Finally, optical depth was found to significantly cor- relate only with nss- $\mathrm{Ca}^{2+}$. Since nss- $\mathrm{Ca}^{2+}$ values measured in Crete as well as at other locations of the eastern Mediterranean compare well with the total $\mathrm{Al}$ concentration concurrently measured, the significant correlation between nss- $\mathrm{Ca}^{2+}$ and O.D indicates the role of dust in regulating the O.D. above the area.

[36] Acknowledgments. We thank the European Commission, Environment and Climate Programme, (ENV4-CT97-0623), University of Crete (ELKE) for financial support, Helene Cachier for the loan of Magee aethalometer, and Maria Kanakidou for helpful comments.

\section{References}

Ayers, G. P., R. W. Gillet, J. M. Cainey, and A. L. Dick, Chloride and bromide loss from the sea-salt particles in southern Ocean air, $J$. Atmos. Chem., 33, 299-319, 1999.

Bardouki, H., Spatial and seasonal variability of DMS(X) species in the Eastern Mediterranean Sea, master thesis, Univ. of Crete, Heraklion, Greece, 2000.

Belviso, S., S. K. Kim, F. Rassoulzadegan, B. Krajka, B. C. Nguyen, N. Mihalopoulos, and P. Buat-Menard, Production of dimethylsulfonium propionate (DMSP) and dimethylsulfide (DMS) by a microbial food web, Limnol. Oceanogr., 35, 1810-1821, 1990.

Charlson, R. J., J. Langner, H. Rodhe, C. B. Leovy, and S. G. Warren, Perturbation of the northern hemisphere radiative balance by backscattering from anthropogenic sulfate aerosols, Tellus, Ser. AB, 43, 152-163, 1991.

Dayan, U., J. L. Heffter, J. M. Miller, and G. Gutman, Dust intrusion 
events into the Mediterranean basin, J. Appl. Metorol., 30, 11851199, 1991.

Dentener, F., F. Carmichael, Y. Zhang, J. Lelieveld, and P. Crutzen, Role of mineral aerosol as a reactive surface in the global troposphere, J. Geophys. Res., 101, 22,869-22,889, 1996.

Draxler, R. R., and G. D. Hess, An overview of the HYSPLIT 4 modelling system for trajectories, dispersion and deposition, Aust. Meteorol. Mag., 47, 295-308, 1998.

Ganor, E., and Y. Mamane, Transport of Saharan dust across the Eastern Mediterranean, Atmos. Environ., 16, 581-587, 1982.

Gogou, A., E. Stephanou, N. Stratigakis, J. O. Grimalt, R. Simo, M. Aceves, and J. Albaiges, Differences in lipid and organic salt constituents of aerosols from Eastern and Western Mediterranean coastal sites, Atmos. Environ., 28, 1301-1310, 1994.

Groene, T., Biogenic production and consumption of dimethylsulfide (DMS) and dimethylsulfoniopropionate (DMSP) in the amrine epipelagic zone: A review, J. Mar. Syst., 6, 191-209, 1995.

Hansen, A. D. A., H. Rosen, and T. Novakov, The aethalometer- An instrument for the real-time measurement of optical absorption by aerosol particles, Sci. Total Environ., 36, 191-196, 1984.

Hess, M., P. Koepke, and I. Schult, Optical properties of aerosols and clouds: The software package OPAC, Bull. Am. Meteorol. Soc., 79, 831-844, 1998.

Ichoku, C., et al., Interrelationships between aerosol characteristics and light scattering during late winter in an eastern Mediterranean arid environment, J. Geophys. Res., 104, 24,371-24,393, 1999.

Intergovernmental Panel on Climate Change (IPCC), Climate Change 1995, edited by J. T. Houghton et al., 339 pp., Cambridge Univ. Press, New York, 1996.

Kavouras, I., N. Mihalopoulos, E. Stephanou, C. Liousse, H. Cachier, B. C. Nguyen, F. Dulac, M. Kanakidou, P. Chazette, and J. P. Quisefit, Measurements of aerosol composition and optical depth above the Eastern Mediterranean Area, paper presented at the 21st General Assembly of the European Geophysical Society, The Hague, May 6-9, 1996.

Keene, W. C., R. Sander, A. A. P. Pzenny, R. Vogt, P. J. Crutzen, and J. N. Galloway, Aerosol pH in the marine boundary layer: A review and model evaluation, J. Aerosol. Sci., 29, 339-356, 1998.

Kouvarakis, G., and N. Mihalopoulos, Seasonal variation of dimethylsulfide in the gas phase and of methanesulfonate and non-sea-salt sulfate in the aerosol phase measured in the eastern Mediterranean atmosphere, Atmos. Environ., 36(6), 929-938, 2002.

Kouvarakis, G., K. Tsigaridis, M. Kanakidou, and N. Mihalopoulos, Temporal variations of surface regional background ozone over
Crete Island in southeast Mediterranean, J. Geophys. Res., 105, 4399-4407, 2000.

Kouvarakis, G., N. Mihalopoulos, T. Tselepides, and S. Stavrakakis, On the importance of atmospheric inputs of inorganic nitrogen species on the productivity of the eastern Mediterranean Sea, Global Biogeochem. Cycles, 15(4), 805-818, 2001.

Kouvarakis, G., H. Bardouki, and N. Mihalopoulos, Sulfur budget above the eastern Mediterranean: Relative contribution of anthropogenic and biogenic sources, Tellus, 54, 201-213, 2002.

Maring, H., D. Savoie, M. A. Izaguirre, C. McCormick, R. Arimoto, J. M. Prospero, and C. Pilinis, Aerosol physical and optical properties and their relationship to aerosol composition in the free troposphere at Izana, Tenerife, Canary Islands, during July 1995, J. Geophys. Res., 105, 14,677-14,701, 2000.

Mihalopoulos, N., E. Stephanou, M. Kanakidou, S. Pilitsidis, and P. Bousquet, Tropospheric aerosol ionic composition above the Eastern Mediterranean Area, Tellus, Ser. B, 314-326, 1997.

Moulin, C., F. Dulac, C. E. Lambert, P. Chazette, B. Chatenet, and F. Lavenu, Long-term daily monitoring of Saharan dust load over ocean using Meteosat ISCCP-B2 data, 2, Accuracy of the model and validation using Sun photometer measurements, J. Geophys. Res., 102, 16,959-16,969, 1997a.

Moulin, C., F. Guillard, F. Dulac, and C. E. Lambert, Long-term daily monitoring of Saharan dust load over ocean using Meteosat ISCCP-B2 data, I, Methodology and preliminary results for 19831994 in the Mediterranean, J. Geophys. Res., 102, 16,947-16,958, $1997 b$.

Seinfeld, J., and S. Pandis, Atmospheric Chemistry and Physics: From Air Pollution to Climate Changes, John Wiley, New York, 1998.

Zerefos, C. S., Photochemical activity and solar ultraviolet radiation modulation factors (PAUR): An overview of the project, J. Geophys. Res., 107(DX), 10.1029/2000JD000134, in press, 2002.

M. Blumthaler, Institute of Medical Physics, University of Innsbruck, A-6020 Innsbruck, Austria.

Y. Doukelis and S. Rapsomanikis, Laboratory of Air Pollution, Department of Environmental Engineering, Demokritos University of Thrace, 67100 Xanthi, Greece.

G. Kouvarakis and N. Mihalopoulos (corresponding author), Environmental Chemical Processes Laboratory, Department of Chemistry, University of Crete, P.O. Box 1470, 71409 Heraklion, Greece. (mihalo@chemistry.uoc.gr)

J. Sciare, LSCE, Orme des Merisiers, Bat 709, CE Saclay, 91191 Gif-sur-Yvette Cedex, France. 